\title{
Application of ultrasonic measurement method for investigation of green ceramic tiles
}

\author{
M. Kulokas, R. Kažys, L. Mažeika \\ Ultrasound Institute, Kaunas University of Technology, \\ Studentu 50, LT-51368 Kaunas, Lithuania, \\ Phone: +370 37 351162, Fax. +370 37451489
}

\begin{abstract}
High quality requirements are established for ceramic tiles manufacturing, because they must be weather-resistant, durable, in general, hard, wear and corrosion resistant and also can withstand high stresses at elevated temperatures. One of the possible control methods of the manufactured tiles quality is ultrasonic method based on measurement of ultrasonic wave propagation speed. However, measurements of ultrasonic wave velocity in green ceramic tiles with an uneven surface are difficult. Therefore attention must be directed to the individual measurement problems of this method, which are the following: uneven surface of the inspected tile; necessity of a dry acoustic contact, non-uniform elastic properties of the tested tile.
\end{abstract}

Keywords: ultrasonic propagation speed, ceramic tile, zero-crossing and the cross-correlation technique.

\section{Introduction}

All manufacturers are constantly looking for ways to reduce the number of defective green ceramic tiles and to reduce consumption of raw materials. That leads to improvement and ensuring of quality and durability of the final product using various quality control systems, which perform the required measurements on-line.

Since ultrasonic measurement system can be installed in tiles manufacturing presses or just behind him, the bad products can be immediately removed and returned for recycling and thus reducing the spoiled tiles and raw material consumption.

The green ceramic tiles are isotropic, therefore velocities of the ultrasonic longitudinal $c_{L}$ and transverse $c_{T}$ waves should not depend on a propagation direction [1-3]. However, the physical properties of tiles affect the ultrasound velocity $[1,6,7-11]$, therefore elastic properties and density of tiles may be estimated by dynamic ultrasonic and vibration resonant frequency measurements $[1,4,5]$.

Since the tiles are manufactured from different raw materials blends, there mechanical properties are not uniform in space, what after firing may lead to defective deformed tiles. Application of ultrasonic measurements enabling to monitor a spatial distribution of corresponding mechanical properties in tiles would enable to detect earlier the defective green ceramic tiles and to return them for recycling. Therefore, such ultrasonic measurement method should be is very useful improvement of ceramic tiles quality.

Our previous article was devoted to spatial density measurements in green ceramic tiles in zones of the similar thickness. [1].In practice most of tiles are manufactured with one flat surface and with pattern on the opposite surface. It means that in different sectors thickness of a green ceramic tile is different, what complicates ultrasonic measurements.

So, the aim of the research presented in this paper is investigation of spatial ultrasound velocity distributions in green ceramic tiles with varying thickness. For that it was necessary to select and experimentally verify the technique suitable for velocity measurements in tiles with uneven surface and to investigate spatial distributions of ultrasound velocity along the tested tile surface.

\section{Specimen and measurements setup}

For measurements of spatial ultrasound velocity distributions a $0.105 \times 0.105 \mathrm{~m}$ size green ceramic tile, manufactured by "Dvarčioniu Keramika", Lithuania, with a rectangular pattern on the rear side was selected. On the rear side the measurement points were marked by dots, e.g., it can by viewed as discrete matrix of measuring point $\left(x_{i}, y_{j}\right)$, with the size is $(31,31)$ (Fig. 1). The distance between neighboring measuring points was the same and was selected $\Delta d=3 \mathrm{~mm}$.

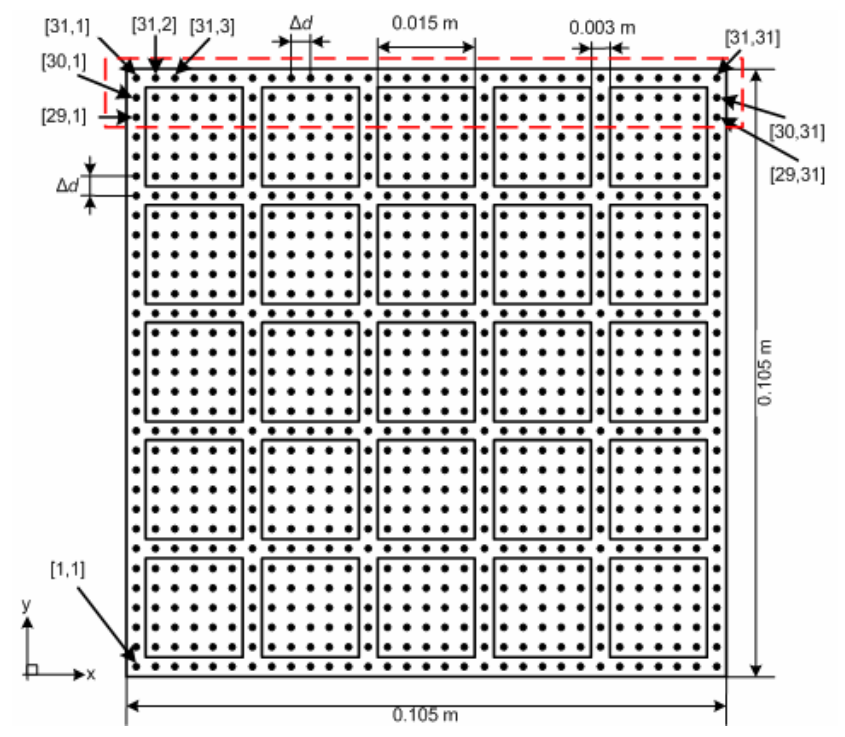

Fig. 1. Green ceramic sample used for ultrasonic longitudinal wave velocity measurements

The ultrasound velocity measurements were performed across the tile at the points $\left(x_{i}, y_{j}\right)$, where $i$ and $j$ are 1,2 , 
$N ; N$ is the number of measurements positions along $x$ and $y$ axis.

The block diagram of the experimental set-up used for measurements is presented in Fig.2. In the previous article devoted to ultrasound velocity measurements in green ceramic samples we have used two identical ultrasonic transducers with a flat surface, which were pressed to tile surfaces in the zones with a similar thickness using a dry acoustic contact between the ultrasonic transducers and the tile [1].

In this case, for ultrasound velocity measurements were used two ultrasonic transducers developed in Ultrasound Institute of Kaunas University of Technology with different acoustic contact zones- for a flat tile surface the transducer with a flat front surface, for the rear side with a pattern the transducer with the point-type contact zone (Fig.2). Such approach was necessary because the thickness of the tile in these zones is quite different.

The diameter of the bigger transducer with a flat contact surface, which was used as a transmitter, was 25 $\mathrm{mm}$. The transducer with a small contact surface $(<1 \mathrm{~mm})$ was used as a receiver and was placed on the rear side of the tile. The frequency of both transducers was $1.0 \mathrm{MHz}$

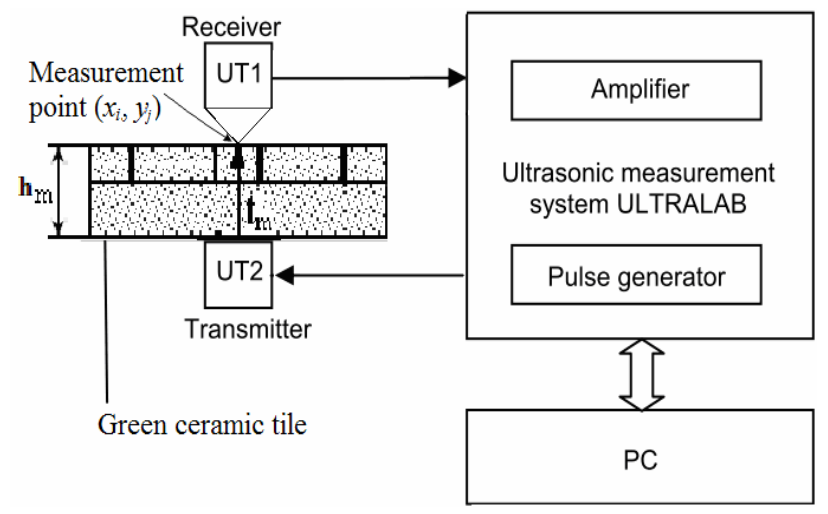

Fig. 2. The set up of ultrasonic measurement system for investigation of longitudinal ultrasonic wave's propagation in green ceramic tiles [12]

For measurements ultrasonic pulse throughtransmission technique was applied. During measurements a dry acoustic contact between ultrasonic transducers and the ceramic sample was used, because otherwise properties of the sample will be affected by a liquid, usually used for acoustic coupling. In order to obtain spatial distributions of ultrasound velocities, measurements were subsequently performed at different marked measurement points $\left(x_{i}, y_{j}\right)$.

At each point the tile thickness $h\left(x_{i}, y_{j}\right)$ was measured by a micrometer and the ultrasonic wave propagation time $t\left(x_{i}, y_{j}\right)$ was measured by the ultrasonic measurement system ULTRALAB developed in the Ultrasound Institute, Kaunas University of Technology. Ultrasonic velocity values were calculated at each point:

$$
c\left(x_{i}, y_{j}\right)=\frac{h\left(x_{i}, y_{j}\right)}{t\left(x_{i}, y_{j}\right)} .
$$

\section{Ultrasound velocity measurements}

The ultrasonic signals used for measurements are presented in Fig. 3. For the propagation time measurements the zero-crossing [1, 13 - 19] and the crosscorrelation [1] methods at the laboratory conditions may be applied. Both algorithms were described in detail in our paper [1].

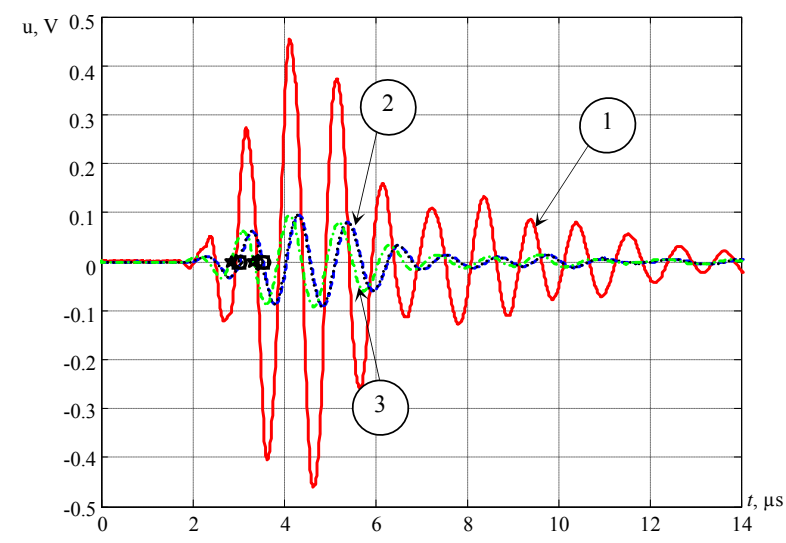

Fig. 3. Ultrasonic signals used for measurements: 1 - the reference signal, 2 - the signal transmitted through the sample, but shifted back in the time domain using the delay time estimated according to the zero-crossing technique; 3 - signal transmitted through the sample, but shifted back in the time domain using the delay time estimated using the cross-correlation technique

Measurements by both methods were performed in the rectangular tile sector marked by a dashed line, e.g., (1-30, 29), (1-30, 30) and (1-30, 31) (Fig. 1). First of all the sample thickness $h\left(x_{i}, y_{j}\right)$ was measured at all measurement points by a micrometer with an uncertainty $0.01 \mathrm{~mm}$. Then at the same points the propagation time $t\left(x_{i}, y_{j}\right)$ of a longitudinal ultrasonic wave was measured with an uncertainty $12 \mathrm{~ns}$ by using the computerized measuring system.

Each measurement result of the ultrasonic wave propagation time $t\left(x_{i}, y_{j}\right)$ was recorded in a computer memory and then using the measured tile thickness the ultrasound velocity of $c\left(x_{i}, y_{j}\right)$ using Eq. 1 was estimated.

Each value of $c\left(x_{i}, y_{j}\right)$ was recorded in a computer memory and was displayed as a spatial velocity distribution of $c\left(x_{i}, y_{j}\right)$ using the coordinate system related to the tested tile (Fig.1).

The measurement results are presented in Fig. $4-6$. The obtained results clearly show that the spatial distribution of ultrasound velocity $c\left(x_{i}, y_{j}\right)$ in the sample is not uniform, what indicates that distribution of mechanical properties and, particularly of the density, is not uniform as well. Let us compare the results obtained by the zerocrossing and the cross-correlation techniques.

In Fig.4- 6 measurement results obtained by both methods are presented. The differences between those two methods are shown in Fig. 7. From the results obtained follows that there is no essential differences, except some systematic shift, which may be eliminated by a calibration. For example, the average ultrasound velocity in the sector of the tile $(1-30,31)$ using zero-crossing technique is equal to $1250 \mathrm{~m} / \mathrm{s}$. Correspondingly, when using the crosscorrelation technique the average ultrasound velocity is $1230 \mathrm{~m} / \mathrm{s}$. Similar results are obtained in neighboring sectors of the tile $(1-30,30)$ and $(1-30,29)$. The average ultrasound velocity in those sectors obtained by the zerocrossing technique is the same and equal to $1250 \mathrm{~m} / \mathrm{s}$. The 
cross-correlation technique in the same sectors gives slightly different ultrasound velocity values- $1218 \mathrm{~m} / \mathrm{s}$ and $1215 \mathrm{~m} / \mathrm{s}$. It is possible to conclude that in a laboratory conditions both methods demonstrate a similar performance. On the other hand, in the case of in-line measurements the cross-correlation technique should be more preferable due to a better noise robustness.

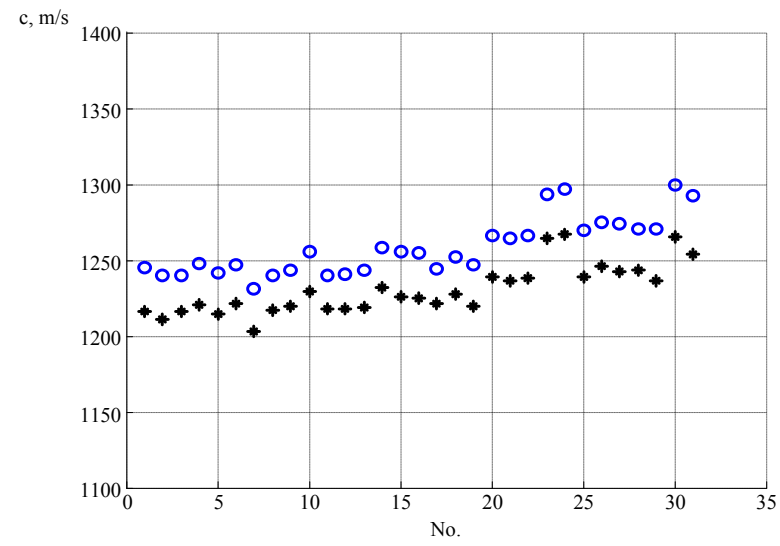

Fig. 4. The ultrasonic longitudinal wave velocity measurements on line $(x, y)$ respectively in sectors of the tile $(1-31,31)$ : 000 results obtained in the sample using the zero-crossing technique; $* * *$ - results obtained on the sample using the cross-correlation technique

The results presented in Fig.4 - 7 show slow and fast spatial variations of ultrasound velocity $c\left(x_{i}, y_{j}\right)$ along the tile. The results obtained indicate that these variations are not measurement errors, but are due variations of mechanical properties in the tile, because there is no essential difference obtained by two different measurement techniques (Fig. 7). The slow variations are very likely to corresponding density $\rho\left(x_{i}, y_{j}\right)$ variations in the tile.

The ultrasound velocity variations in the sector (1-30, $31)$ are $\pm(16-17) \mathrm{m} / \mathrm{s}$ with respect to the average ultrasound velocity independently on the measurement method (Fig. 4).

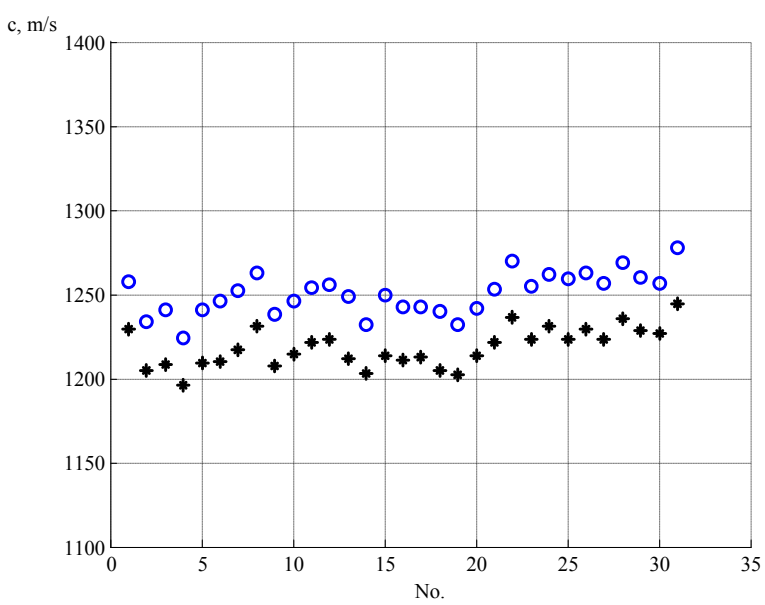

Fig. 5. The ultrasonic longitudinal wave velocity measurements on line $(x, y)$ respectively in sectors of the tile $(1-31,30)$ : 000 results obtained in the sample using the zero-crossing technique; $* * *$ - results obtained on the sample using the cross-correlation technique

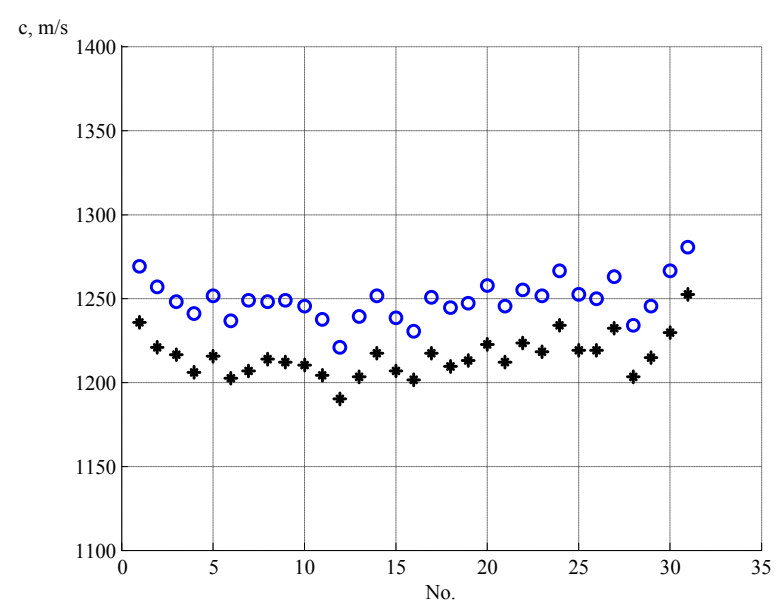

Fig. 6. The ultrasonic longitudinal wave velocity measurements on the line $(x, 29)$ respectively in the sector of the tile $(1-31,29)$ : 000 results obtained on the sample using the zero-crossing technique; $* * *$ - results obtained on the sample using the crosscorrelation technique

In the neighboring sectors of the tile (1-30, 30) and (1$30,29)$ spatial variations of the ultrasound velocity obtained by the zero-crossing and the cross-correlation methods are similar and equal to $\pm(12-13) \mathrm{m} / \mathrm{s}$ (Fig.5 and $6)$.

Since the ultrasound velocity $c\left(x_{i}, y_{j}\right)$ measurements are performed in sectors with different green ceramic tile thickness, therefore the differences of ultrasound velocity values between adjacent measurement points were analyzed also. In this case the $c\left(x_{i}, y_{j}\right)$ value differences along the two lines $(1-31,30)$ and $(1-31,29)$ were determined between the neighboring measurement points located at two different lines- $y=29$ and $y=30$. So determined ultrasonic wave propagation velocity differences at sectors of the tile $((1-31,30)$ and $(1-31,29))$ are presented in Fig. 7, with allows to determine the differences between the measured values $c\left(x_{i}, y_{j}\right)$ along the axis $y$ also.

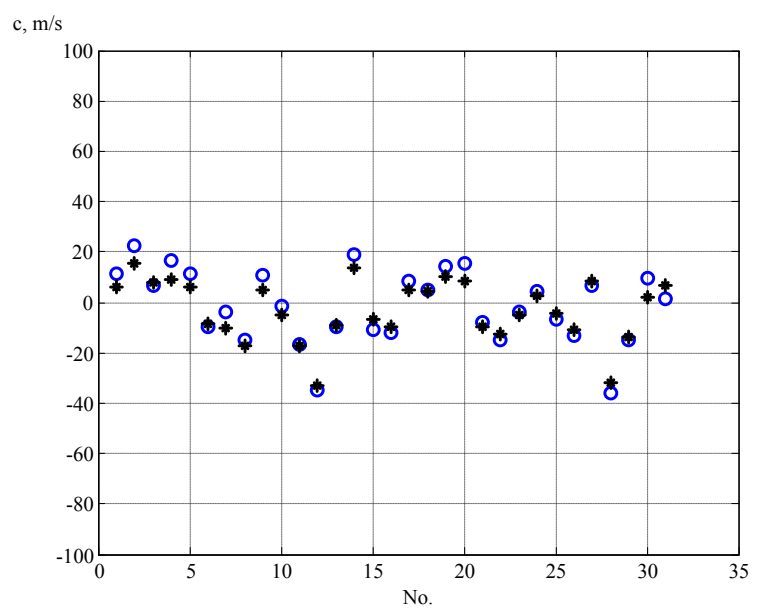

Fig. 7. The difference between the ultrasonic longitudinal wave velocity measurements along the lines $(1-31,30)$ and $(1-31$, 29) in the marked sector of the tile: 000 - results obtained using the zero-crossing technique; $* * *$ - results obtained using the cross-correlation technique 


\section{Conclusions}

1. The obtained results clearly show that a spatial distribution of the ultrasound velocity $c\left(x_{i}, y_{j}\right)$ in the green ceramic tiles is not uniform, what indicates that distribution of mechanical properties and, particularly of the density, is not uniform as well.

2. The results obtained by the zero-crossing and the cross-correlation techniques give very similar results, except some systematic shift, which may be eliminated by a calibration.

3. The obtained spatial ultrasound distributions of ultrasound velocity $c\left(x_{i}, y_{j}\right)$ allow to determine the minimal distance between the measurement points, necessary for accurate reconstruction of ultrasound velocity spatial distributions.

4. The ultrasound velocity variations in the sector (1-30, 29) - $(1-30,31)$ reach $\pm(16-17) \mathrm{m} / \mathrm{s}$ with respect to the average ultrasound velocity independently on a measurement method.

\section{Acknowledgement}

We would like to thank Dr. A. Vladišauskas for supplying ultrasonic transducers and Dr. R. Šliteris for the help during experiments.

\section{References}

1. Kulokas M., Kažys R., Mažeika L. Non-destructive evaluation of green ceramic body density by ultrasonic technique. Electronics and Electrical Engineering. Kaunas: Technologija. 2011. No. 5(111). P. 71-76.

2. Revel G. M., Tomasini E. P. Non-contact ultrasonic sensor for online density measurement on green ceramic tiles. $15^{\text {th }}$ World Conference on Nondestructive Testing. Roma (Italy) 15-21 October 2000. Link to the internet

$<$ http://www.ndt.net/article/wcndt00/papers/idn708/idn708.htm> (2011-03-20).

3. Aston S. D., Challis R. E. and Yiasemides G. P. Density mapping of ceramic tiles by compression-wave ultrasound. Nondestructive Testing and Evaluation. 2007. Vol. 17. P. 263-273.

4. Amoros J. L. Clay ceramics for floors single firing. Influence of variables of pressing on the properties of the part in oil and on their behavior during the press and cooking. University of Valencia. 1987. P. 61-187. [PhD Thesis].

5. Kathrina T., Rawlings R. D. Non-destructive evaluation of porous $\mathrm{MgO}$ ceramics using acoustic techniques. Journal of material science. 1997. Vol. 32. P. 3951-3959.

6. Wróbel G., Wierzbicki L. Ultrasonic methods in diagnostics of polyethylene. International Scientific Journal Vol. 28. 2007. P. 413416.

7. Rabe T., Rudert R., Goebbels J., Harbich K.-W. Nondestructive evaluation of green components. American Ceramic Society Bulletin. 2003. Vol. 82. No. 3. P. 27-32.

8. Rodroquez M. A., Vergara L., Miralles R. Nondestructive evaluation of microcracks in ceramics with controlled probability of false alarm. Res. Nondestr. Eval. 1999. Vol. 11. P. 15-24.
9. Kim J., Liaw P. K. The nondestructive evaluation of advanced ceramics and ceramic-matrix composites. Nondestructive Evaluation: Overview. 1998. Vol.50. No.11. P. 1-15.

10. Rodriquez M. A., Miralles R., Vergara L. Signal processing for ultrasonic non-destructive evaluation: two applications. NDT\&E International. 1998. Vol. 31. No. 2. P. 93-97.

11. Romagnoli M., Burani M., Tari G., Ferreira J. M. F. A nondestructive method to assess delamination of ceramic tiles. Journal of the European Ceramic Society. 2007. Vo. 27. P. 1631-1636.

12. Mažeika L., Šliteris R., Vladišauskas A. Measurement of velocity and attenuation for ultrasonic longitudinal waves in the polyethylene samples. ULTRASOUND. 2010. Vol. 65. No. 4.

13. Kuc R. Processing of diagnostic ultrasound signals. IEEE Acous. Speech Signal Process. Mag. 1984. P. 19-26.

14. Kuc R. Estimating acoustic attenuation from reflected ultrasound signals: comparison of spectral-shift and spectral-difference approaches. IEEE Trans. Acous. Speech Signal Process. 1984. Vol. 32. P. 1-6.

15. Mallat S. Zero crossings of a wavelet transform. IEEE Trans Inform Theory. 1991. Vol. 37. P. 1019-32.

16. Barkhatov V. A. Normalizing ultrasonic pulses in time-delay and distance measuring systems. Russian journal of nondestructive testing. 2009. Vol. 45. No. 6. P. 425-429.

17. Srinivasan S. and Ophir J. A zero-crossing strain estimator in elastography. Ultrasound Med. Biol. 20003. Vol. 29. No. 2. P. 227238 .

18. Jacovitti G. and Scarano G. Discrete time techniques for time delay estimation. IEEE Trans. Acoust. Speech Signal Process. 1993. Vol. 41. P. 525-533.

19. Langeland S., Dapos J., Torp H., Bijnens B., and Suetens P. A simulation study on the performance of different estimators for twodimensional velocity estimation. in proc. IEEE Ultrasonics Symp. Oct. 8-11. 2002. Vol. 2. P. 1859-1862.

\section{Kulokas, R. Kažys, L. Mažeika}

Ultragarso bangų sklidimo greičio, išmatuoto keraminès plytelès ruošinyje, analizè

Reziumè

Keraminių plytelių gamybai keliami dideli kokybès reikalavimai jos turi būti ilgaamžès, patvarios, atsparios aplinkos ir aukštos temperatūros poveikiui. Vienas iš plytelių kokybès galimų kontrolinių matavimų atliekami naudojant ultragarsą. Tačiau dèl nelygaus plytelių paviršiaus ultragarso bangu sklidimo greiti matuoti yra sudètinga. Todėl svarbu išnagrinèti problemas, dèl kurių minèti matavimai turi sunkumų: tiriamos plytelès paviršiuc, plytelès gamybai naudojamas žaliavas, pačios plytelès anizotropiją ir tamprumo savybes. 